\title{
The first record of Salsola paulsenii (Chenopodiaceae) in Ukraine, with taxonomic and nomenclatural comments on related taxa
}

\author{
Sergei L. MOSYAKIN \\ M.G. Kholodny Institute of Botany, National Academy of Sciences of Ukraine \\ 2, Tereschenkivska Str., Kyiv (Kiev) 01004, Ukraine \\ s_mosyakin@hotmail.com
}

Mosyakin S.L. The first record of Salsola paulsenii (Chenopodiaceae) in Ukraine, with taxonomic and nomenclatural comments on related taxa. Ukr. Bot. J., 2017, 74(5): 409-420.

Abstract. Salsola paulsenii (Chenopodiaceae) is reported for Kyiv: several plants were found (September 2017) in a sandy ruderal area of the northwestern part of Obolon, along railway tracks leading to the grain elevator and brewery facilities of the Obolon Joint-Stock Co. Some co-occurring plants may represent hybrids of $S$. paulsenii and $S$. tragus. Data on morphology and distribution of $S$. paulsenii and related species are provided. If established, this species may become an invasive weed in Ukraine. Recent changes in taxonomy and nomenclature of Salsola sensu lato are discussed. Nomenclatural information is provided for species of the Ukrainian flora formerly reported in Salsola sensu lato and now placed in Salsola sensu stricto (incl. Kali), Soda, Caroxylon, Climacoptera, and Pyankovia. Keywords: Salsola, Kali, Chenopodiaceae, Salsoloideae, nomenclature, taxonomy, floristic record, alien species

\section{Introduction}

The genus Salsola L. (Chenopodiaceae: Salsoloideae: Salsoleae) is currently understood in a new restricted circumscription as compared to treatments of that group in many earlier floras and manuals (Iljin, 1936, 1952; Aellen, 1960-1961; Grubov, 1966; Botschantzev, 1969; Pratov, 1972; Lomonosova, 1992; Kühn, 1993; Freitag, Rilke, 1997; Rilke, 1999; Freitag, 2001; Zhu et al., 2003 etc.). These taxonomic and nomenclatural changes resulted from molecular phylogenetic studies (Pyankov et al., 2001a, b; Kadereit et al., 2003; Kapralov et al., 2006; Akhani et al., 2007; Wen et al., 2010 etc.) and partly also morphological and anatomical evidence (Wen, Zhang, 2011; Voznesenskaya et al., 2013; Sukhorukov, 2014 etc.). Recent controversy regarding the proper application of the name Salsola and typification of that generic name (Akhani et al., 2007, 2014; Mosyakin et al., 2014, 2017) resulted in a temporary but widespread application of the generic name Kali Mill. to the clade containing $S$. kali L., while the name Salsola was applied to the clade containing S. soda L. (Sukhorukov, 2014; Brullo et al., 2015a, b; Hernández-Ledesma et al., 2015 etc.). However, this controversy was resolved by the nomenclatural

(C) S.L. MOSYAKIN, 2017 conservation of Salsola with S. kali L. as the conserved type (Wilson, 2017). Thus, the group containing most widespread and often weedy species, such as $S$. tragus $\mathrm{L}$. and its relatives, retained the generic name Salsola sensu stricto, and the generic name Soda Fourr. is currently applied to the clade containing Soda inermis Fourr. (formerly Salsola soda L.). However, further and ongoing molecular studies indicate that the Soda clade will be most probably split into several segregate genera (Mosyakin et al., 2017).

Most species of Salsola sensu stricto occur in the continental arid regions of Asia, with some taxa extending or native to western coastal Europe, the Mediterranean region, coastal Asia, and Australia. Despite the revision by Rilke (1999), the taxonomy of certain entities of the $S$. tragus aggregate remains problematic. In particular, there are probably some additional taxa (including cryptic species) in continental Asia, yet undescribed or already described but not recognized in recent taxonomic treatments. In addition to $S$. australis R. Br. recently taxonomically restored by Hrusa and Gaskin (2008), several other Australian species such as S. macrophylla $\mathrm{R}$. Br. and infraspecific taxa of "S. kali" described by Bentham (1870), which were included in a polymorphic $S$. kali by Wilson (1984) and in $S$. tragus by Rilke (1999), will be probably also restored following 
more thorough studies (see preliminary data in Borger et al., 2008; Chinnock, 2010).

Synonymization of the Australian taxon S. macrophylla with the Pontic (and eastern Mediterranean?) S. pontica (Pall.) Degen (= Kali ponticum (Pall.) Sukhor., S. tragus subsp. pontica (Pall.) Rilke) cursorily done by Rilke (1999) and later accepted by Galasso and Bartolucci (2014), who coined the combination Kali macrophyllum (R. Br.) Galasso \& Bartolucci, seems to be at least questionable. Their identity has not been proven yet beyond doubt, and until such a proof is available, I prefer to use the name $S$. pontica for our plants. This taxon, which was described from the Black Sea shores of Crimea, Ukraine, as $S$. kali var. pontica Pall., belongs to a problematic group of Pontic-Mediterranean coastal taxa currently known as $S$. pontica (either sensu lato or sensu stricto) and Kali dodecanesicum C. Brullo, Brullo, Giusso \& Ilardi (Brullo et al., 2015b). No nomenclatural combination in Salsola is currently available for the latter taxon; however, it is quite possible that it is in fact conspecific with $S$. controversa Tod. ex Lojac. described from Sicily (Lojacono Pojero, 1904: 271-272), which in that case will be the correct name for this Mediterranean species (if it is indeed specifically distinct from $S$. pontica), or for the whole PonticMediterranean coastal group (if treated as one species, incl. $S$. pontica). Of course, the identity of two earlier species-rank names ( $S$. macrophylla described from Australia and $S$. brachypteris Moq. described from Java, Indonesia) mentioned by Rilke (1999) in synonymy of her $S$. tragus subsp. pontica should be critically assessed as well. It should be noted that in IPNI (2017-onward) and in some other sources $S$. controversa was reported with the authorship "Tod. ex Nyman - Consp. Fl. Eur. 3: 631. 1881"; however, that name was mentioned by Nyman in synonymy only and without any description or diagnosis; thus, it was not validly published in 1881. In contrast, Lojacono Pojero (1904) accepted that species in his Flora Sicula and provided its rather detailed description.

To add to the confusion, Michalková and Letz (2014) recently claimed (contrary to opinions of Tzvelev, Mosyakin, Rilke, Sukhorukov and many other experts expressed in many recent publications; see References) that the Linnaean name $S$. tragus was in fact misapplied to the most widespread weedy taxon of Salsola (which Michalková and Letz called S. kali subsp. ruthenica "(Iljin) Soó") and should be used instead as the correct name for the coastal Mediterranean taxon only, incl.
S. pontica as a synonym of $S$. tragus in that "coastal" sense. Michalková and Letz (2014) characterized that coastal taxon as having "distinctly succulent leaves, bracts and bracteoles; bracts long spine-tipped". However, anyone can see that the lectotype of $S$. tragus (LINN 315.3; digital image available from http://linnean-online. org/3160/), in contrast to another original specimen ( $L I N N 315.5$, not the lectotype!), is a plant with rather narrow and almost non-succulent leaves and not so prominently spiny bracts and bracteoles, quite well corresponding to the current concept of $S$. tragus. The issue of lectotypification of $S$. tragus was exhaustively discussed by Tzvelev (1993), Rilke (1999) and other authors, so there is no need to change again its current well-established application.

Several species of Salsola were unintentionally introduced by human activities (mainly agriculture and trade) far beyond their native ranges and became invasive weeds in many parts of the world. In particular, the iconic tumbleweeds of the North American Southwest are in fact quite recent invaders. The most widespread weedy species $S$. tragus (also widely known in the past as $S$. pestifer A. Nelson, S. ruthenica Iljin, nom. illeg., $S$. kali subsp. ruthenica Soó, S. iberica (Sennen \& Pau) Botsch. ex Czerep., and under the misapplied names S. australis auct. non R. Br. and S. kali auct. p.p., non L.) started its colonization of North America only closer to the end of the $19^{\text {th }}$ century (Beatley, 1973; Crompton, Bassett, 1985; Mosyakin, 1996, 2003; Beckie, Francis, 2009 and references therein). However, as it has been demonstrated by recent thorough studies using molecular, morphological and ecological approaches (Ryan, Ayres, 2000; Gaskin et al., 2006; Ryan et al., 2007; Hrusa, Gaskin, 2008; Smith et al., 2013; Welles, Ellstrand, 2016a, b), in southwestern North America (and in California in particular) several species introduced from Eurasia (S. tragus, S. paulsenii Litv.) and Australia ( $S$. australis) are involved in active microevolutionary processes resulting in the emergence of highly invasive weedy races, such as the recently identified allohexaploid $S$. ryanii Hrusa \& Gaskin (= Kali ryanii (Hrusa \& Gaskin) Brullo \& Hrusa) that originated from hybridization of diploid $S$. australis and tetraploid $S$. tragus. Now this hybridogenous species is rapidly spreading in California (Welles, Ellstrand, 2016a). Moreover, it has been recently demonstrated that "this neo-invasive is the result of three independent admixture events and that gene flow among the individual lineages is just beginning, leading to withinspecies admixture" (Ellstrand, Rieseberg, 2016: 834; 
Table 1. Salsola sensu lato in Ukraine: names used in major floristic treatments, and currently accepted names

\begin{tabular}{|c|c|c|c|c|c|}
\hline Iljin (1952) & Skripnik (1987) & Tzvelev (1996) & $\begin{array}{c}\text { Mosyakin \& } \\
\text { Fedoronchuk (1999) }\end{array}$ & Sukhorukov (2014) & $\begin{array}{c}\text { Currently accepted } \\
\text { names }\end{array}$ \\
\hline \multicolumn{6}{|c|}{ Salsola L. sensu stricto } \\
\hline $\begin{array}{l}\text { Salsola collina Pall., } \\
\text { mentioned in a } \\
\text { footnote }\end{array}$ & $\begin{array}{l}\text { not reported for } \\
\text { Ukraine }\end{array}$ & Salsola collina Pall. & Salsola collina Pall. & $\begin{array}{l}\text { Kali collinum (Pall.) } \\
\text { Akhani \& Roalson }\end{array}$ & Salsola collina Pall. \\
\hline $\begin{array}{l}\text { not reported for } \\
\text { Ukraine }\end{array}$ & $\begin{array}{l}\text { not reported for } \\
\text { Ukraine }\end{array}$ & $\begin{array}{l}\text { Salsola paulsenii Litv., } \\
\text { not reported for Ukraine }\end{array}$ & $\begin{array}{l}\text { not reported for } \\
\text { Ukraine }\end{array}$ & $\begin{array}{l}\text { Kali paulsenii (Litv.) } \\
\text { Akhani \& Roalson, not } \\
\text { reported for Ukraine }\end{array}$ & Salsola paulsenii Litv. \\
\hline $\begin{array}{l}\text { Salsola ruthenica Iljin } \\
\text { var. pontica (Pall.) } \\
\text { Iljin }\end{array}$ & not mentioned & $\begin{array}{l}\text { Salsola pontica (Pall.) } \\
\text { Degen }\end{array}$ & $\begin{array}{c}\text { Salsola kali } \mathrm{L} . \\
\text { subsp. pontica }(\text { Pall.) } \\
\text { Mosyakin } \\
\end{array}$ & $\begin{array}{l}\text { Kali ponticum (Pall.) } \\
\text { Sukhor. }\end{array}$ & $\begin{array}{l}\text { Salsola pontica (Pall.) } \\
\text { Degen }\end{array}$ \\
\hline $\begin{array}{l}\text { Salsola tamariscina } \\
\text { Pall. }\end{array}$ & $\begin{array}{l}\text { Salsola tamariscina } \\
\text { Pall. } \\
\end{array}$ & Salsola tamariscina Pall. & $\begin{array}{l}\text { Salsola tamariscina } \\
\text { Pall. } \\
\end{array}$ & $\begin{array}{c}\text { Kali tamariscinum (Pall.) } \\
\text { Akhani \& Roalson }\end{array}$ & Salsola tamariscina Pall. \\
\hline Salsola ruthenica Iljin & $\begin{array}{c}\text { Salsola iberica, cum } \\
\text { auct. "Sennen \& Pau" }\end{array}$ & Salsola tragus L. & Salsola tragus $\mathrm{L}$. & Kali tragus (L.) Scop. & Salsola tragus L. \\
\hline Salsola soda $\mathrm{L}$. & Salsola soda $\mathrm{L}$. & Salsola soda $\mathrm{L}$. & Salsola soda $\mathrm{L}$. & Salsola soda $\mathrm{L}$. & Soda inermis Fourr. \\
\hline \multicolumn{6}{|c|}{ Caroxylon Thunb. } \\
\hline Salsola laricina Pall. & Salsola laricina Pall. & $\begin{array}{l}\text { Caroxylon laricinum } \\
\text { (Pall.) Tzvelev }\end{array}$ & $\begin{array}{c}\text { Caroxylon laricinum } \\
\text { (Pall.) Tzvelev }\end{array}$ & $\begin{array}{l}\text { Caroxylon laricinum } \\
\text { (Pall.) Tzvelev }\end{array}$ & $\begin{array}{c}\text { Caroxylon laricinum } \\
\text { (Pall.) Tzvelev }\end{array}$ \\
\hline \multicolumn{6}{|c|}{ Climacoptera Botsch. } \\
\hline $\begin{array}{l}\text { Salsola crassa } \\
\text { M.Bieb., reported } \\
\text { as (probably) an } \\
\text { erroneous record }\end{array}$ & $\begin{array}{l}\text { Climacoptera crassa } \\
\text { (M.Bieb.) Botsch., } \\
\text { mentioned as an } \\
\text { erroneous record }\end{array}$ & $\begin{array}{c}\text { Climacoptera crassa } \\
\text { (M. Bieb.) Botsch., } \\
\text { mentioned as (probably) } \\
\text { an erroneous record }\end{array}$ & $\begin{array}{l}\text { Climacoptera crassa } \\
\text { (M. Bieb.) Botsch. }\end{array}$ & $\begin{array}{l}\text { Climacoptera crassa } \\
\text { (M. Bieb.) Botsch., not } \\
\text { reported for Ukraine }\end{array}$ & $\begin{array}{l}\text { Climacoptera crassa } \\
\text { (M. Bieb.) Botsch., } \\
\text { old and most probably } \\
\text { erroneous records, not } \\
\text { confirmed for Ukraine. }\end{array}$ \\
\hline
\end{tabular}

Welles, Ellstrand, 2016b). Also, the first cases of fieldevolved Glyphosate-resistant races of weedy $S$. tragus were recently reported from Montana and Washington states of the USA (Kumar et al., 2017), which indicates the ongoing microevolutionary processes resulting in herbicide resistance in some naturalized populations of the species in North America.

\section{Salsola sensu lato in Ukraine: previous data}

Iljin (1952) reported for Ukraine seven species of Salsola (plus one currently recognized species, S. pontica (Pall.) Degen, was accepted as a variety of $S$. tragus, and $S$. collina Pall. was mentioned in a footnote), of which only three species still remain in that genus. The names of taxa accepted in main relevant floristic publications after Iljin (1952) are summarized in Table 1. It shows that currently the Ukrainian taxa listed by Iljin (1952) and subsequent authors are placed in Salsola sensu stricto, Soda Fourr., Caroxylon Thunb., Climacoptera Botsch., and Pyankovia Akhani \& Roalson. The presence of a species of Climacoptera in Ukraine needs confirmation (probably an erroneous record). The genus Pyankovia was recently segregated from Climacoptera and initially considered monospecific (Akhani et al., 2007); at present Pyankovia contains three species in two sections (Mosyakin, Roalson, 2017). Pyankovia brachiata (Pall.) Akhani \& Roalson (earlier known as Climacoptera brachiata (Pall.) Botsch. and Salsola brachiata Pall.) occurs in Ukraine only in Crimea (Tzvelev, 1996, 2012; Yena, 2012).

There are two alien species of Salsola currently known in Ukraine: S. collina Pall. (Kali collinum (Pall.) Akhani \& Roalson, as "collina") and S. paulsenii, the 


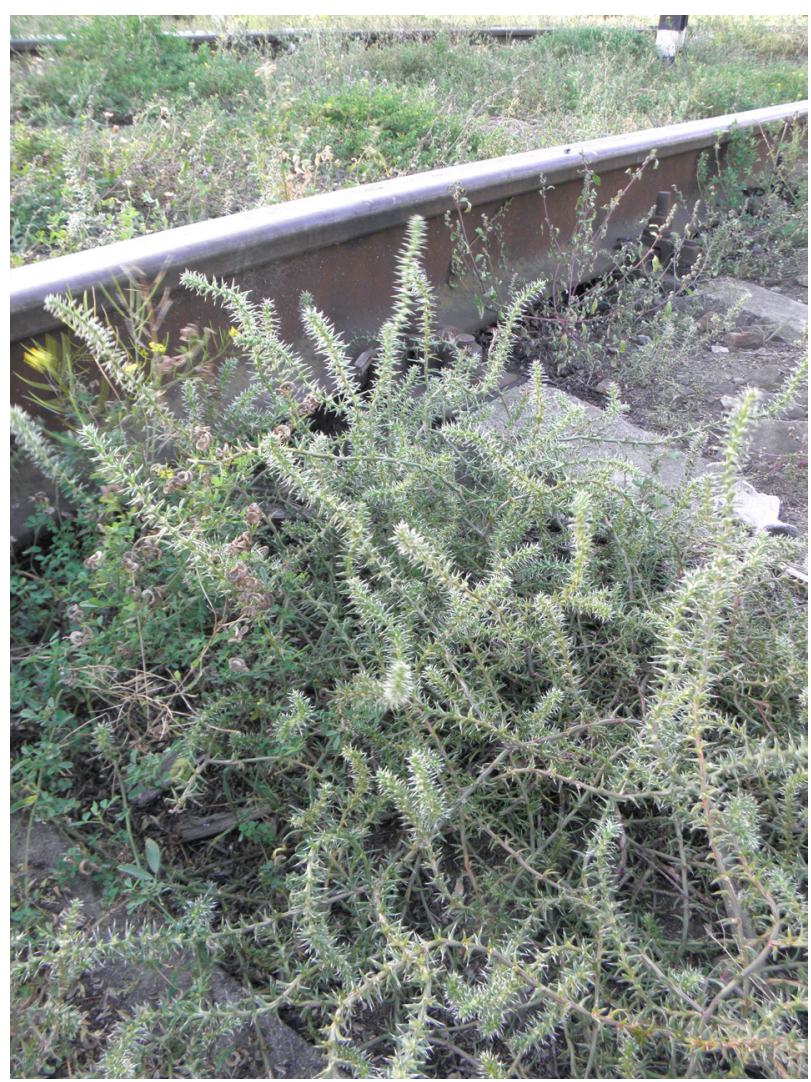

Fig. 1. Salsola paulsenii growing at railway tracks in Kyiv, Obolon. All photographs made in the field in the same locality

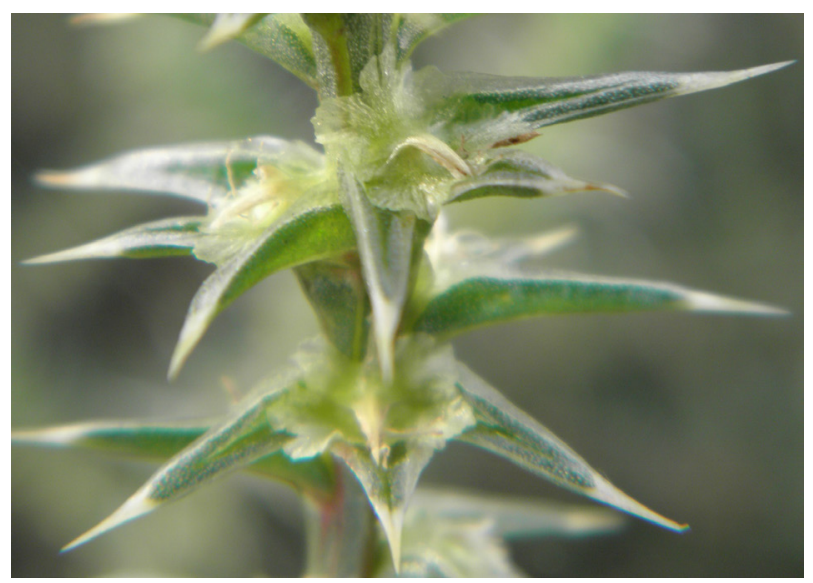

Fig. 2. Salsola paulsenii: close-up of a branch with young fruits and bracts/bracteoles. Note the long protruding column formed by tips of perianth segments above the wings, and the bracts and bracteoles gradually tapering into long spines species reported in the present article. Salsola collina was probably found for the first time in Ukraine by M.V. Klokov and M.I. Kotov near railway tracks in Chuguyiv, Kharkiv Region (mentioned in Iljin 1952: 387 , in adnot., with an exclamation mark indicating that Iljin has seen the specimen). No corresponding voucher specimens from that locality have been traced in KW (herbarium acronyms following Thiers 2017-onward) at present, but misidentification of this species by Iljin is highly improbable. A few earlier records of this species from southern regions of Ukraine (Kherson and/or Odesa) reported in the $19^{\text {th }}$ century (e.g. Schmalhausen, 1886) were evidently based on misidentifications (most probably those of $S$. pontica), as it has been convincingly demonstrated by Iljin (1952: 386-387). Baranova and Khilova (1990) provided on their distribution map a dot in eastern Ukraine (corresponding to Chuguyiv?), but no precise locality or herbarium specimens were reported. Reliable and herbarium-confirmed collections of $S$. collina were made later in several habitats along railways and near grain elevators in Kyiv (Mosyakin, 1988, 1991). Since then $S$. collina is known in Ukraine from several other scattered localities (e.g., Slavuta, Khmelnytsky Region, railway tracks at a grain elevator; collected by Mosyakin in 2001 and reported in Gubar, 2004: 71) and in the Southeast (Ostapko et al., 2010). It still remains in Ukraine a rather uncommon "railroad' plant forming occasionally, however, quite large but local colonies, predominantly in gravel and crushedstone track ballast, or sometimes in nearby sandy habitats. This species is occasionally found in Europe beyond its native range (Aellen 1960-1961; Tzvelev, 1996; Rilke 1999; Vidéki, 2005 etc.) and is spreading in North America (Mosyakin, 1996, 2003; Blondeau et al., 2007; Oldham et al., 2011, and references therein).

\section{The first record of Salsola paulsenii in Ukraine}

During a routine survey of ruderal habitats within the city of Kyiv for search and monitoring of alien species, on 18 September 2017 I found S. paulsenii in the northwestern part of the city, Obolon (Minsky administrative district), along railway tracks near the grain elevator and brewery facilities of the Obolon JointStock Co. (Latitude: N 50³0'34.1879"; Longitude: E $\left.30^{\circ} 28^{\prime} 47.0765^{\prime \prime}\right)$. There were four large and welldeveloped plants growing between railway tracks (Figs $1,2)$ and several smaller and rather underdeveloped plants (some probably affected by herbicides) in a narrow sandy strip along the tracks, ca. 10 meters from the larger plants. Accompanying species were Salsola tragus L. (several morphotypes), Sisymbrium 
Table 2. Comparative table of selected diagnostic characters of Salsola tragus, $S$. paulsenii, S. pontica, and two related potentially invasive species not yet reported from Ukraine*

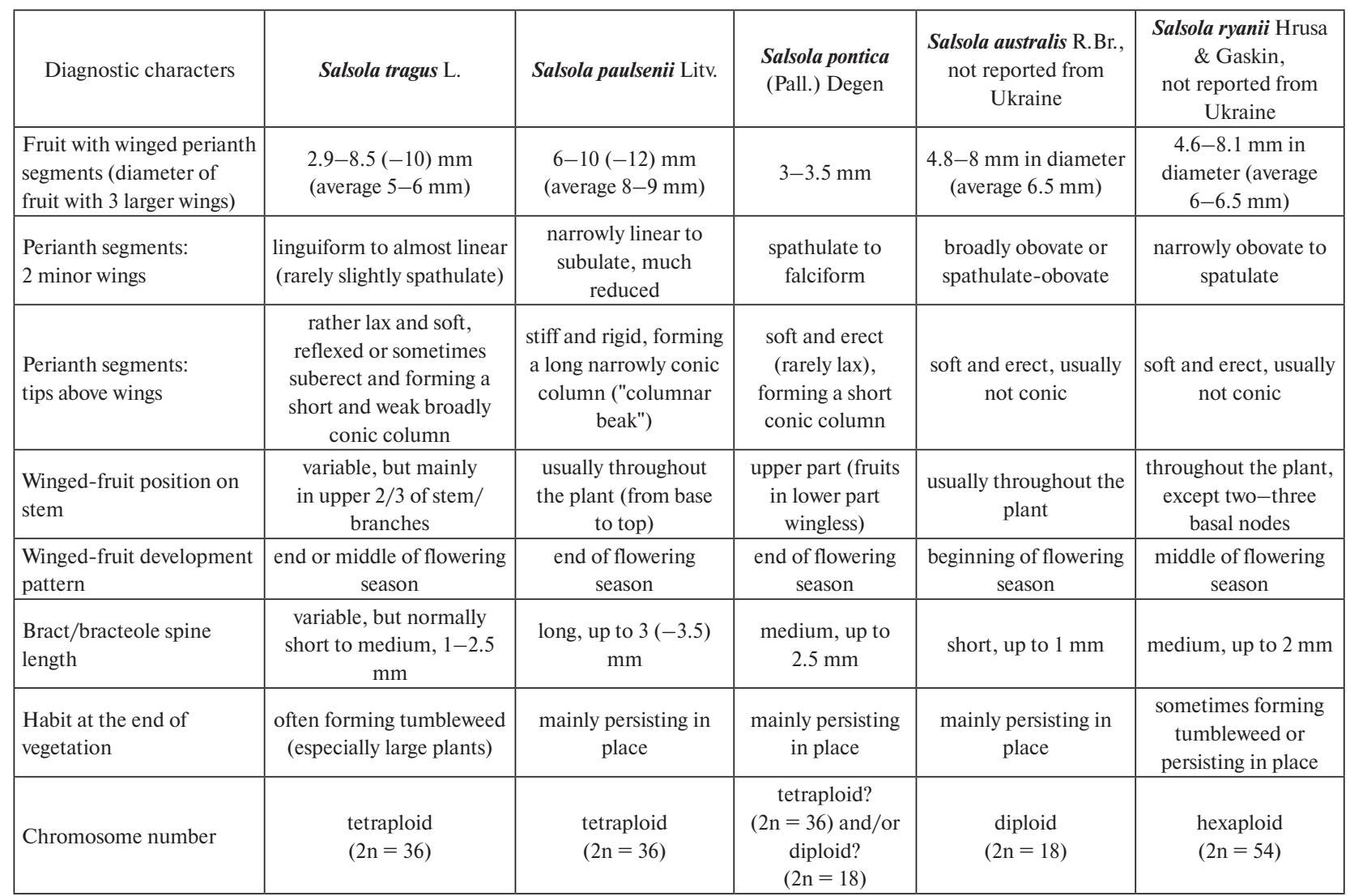

* Based on Iljin (1936); Rilke (1999); Hrusa, Gaskin (2008); Brullo et al. (2015a), etc., and original observations. For additional diagnostic characters, see the references cited in the text.

loeselii L., Grindelia squarrosa (Pursh) Dunal., Setaria viridis (L.) P. Beauv., Eragrostis minor Host, Polygonum aviculare L. aggr., Chenopodium betaceum Andrz. (= C. strictum auct. non Roth; for nomenclatural and taxonomic updates see Mosyakin, 2017), C. album L. aggr.; less commonly also Artemisia vulgaris L., Atriplex tatarica L., Bassia laniflora (S.G. Gmel.) A.J. Scott (= Kochia laniflora (S.G. Gmel.) Borbás), Centaurea stoebe L. aggr., Digitaria sanguinalis (L.) Scop., Erigeron canadensis L. (= Conyza canadens (L.) Cronquist), Medicago sativa L., and some other plants rather common in ruderal habitats in Kyiv.

Salsola paulsenii was co-occurring with another species of Salsola, S. tragus, a very common and morphologically rather diverse species in this locality. A rather representative sampling of $S$. tragus from that habitat (about 25 morphologically diverse plants, KW) was done on 22 September 2017 during my second visit to the Obolon locality. At least two sampled plants of
S. tragus sensu lato were morphologically transitional toward individuals of $S$. paulsenii growing nearby. These atypical plants grew in stands of $S$. tragus sensu stricto and, being habitually similar to typical forms of that species, had elongated tips of perianth segments (tepals) forming a column (Fig. 3). However, these perianth tips were shorter and less rigid than in typical $S$. paulsenii (Table 2). Morphologically these plants fit descriptions of variable presumable hybrids between $S$. tragus and S. paulsenii (reported as $S$. gobicola Iljin, fide Rilke 1999), or probably the morphotype reported from southwestern North America under the informal name "S. paulsenii lax form" (see Hrusa, Gaskin, 2008; Ayres et al., 2009 and references therein). The identity and origin of the North American "lax form" remain obscure. Since that form contained alleles from $S$. tragus, S. paulsenii, and $S$. australis, plus two unique alleles, it may be a complex hybrid involving three or more species (Ayres et al., 2009). Morphological 


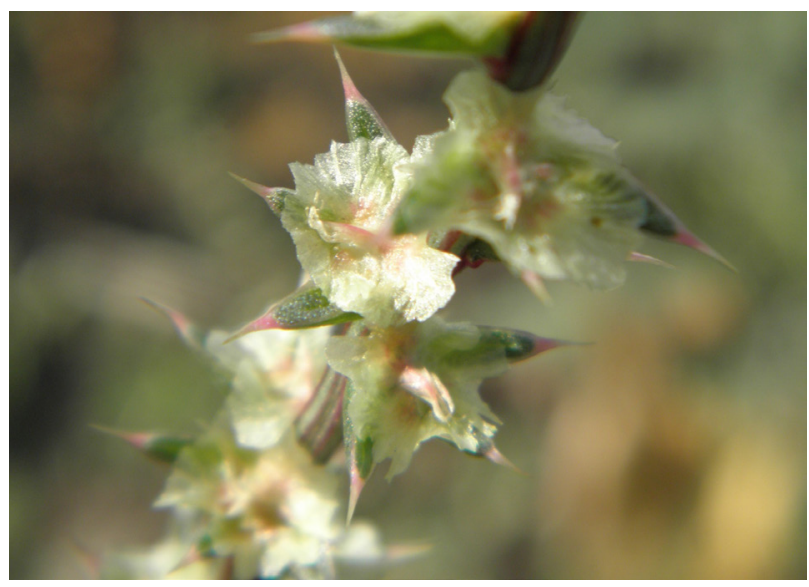

Fig. 3. Plant morphologically intermediate between Salsola paulsenii and $S$. tragus: close-up of a branch with fruits and bracts/bracteoles. Note the long tips of perianth segments (but less rigid than in $S$. paulsenii, and reflexed at apices), the bracts and bracteoles more abruptly contracted into shorter spines, and irregular (eroded or dentate) wing margins

characters reported for $S$. gobicola in the protologue (Iljin, 1955) seem to be perfectly intermediate between those of $S$. paulsenii and $S$. tragus. Additional studies are needed to confirm or refute the possible hybrid nature and origins of those morphologically rather variable Eurasian and North American plants.

Mature fruits of $S$. paulsenii are enclosed in five persistent perianth segments, three of which usually bear rather wide horizontal wing-like appendages. The species is thus well-adapted to dispersal by wind (anemochory). However, in our case it is evident that diaspores of $S$. paulsenii were introduced to the locality with grain transported by railroad to the elevator and brewery. Possible immediate geographical sources of introduction are discussed below. Considering the potential invasive nature of $S$. paulsenii and the availability of nearby sandy habitats suitable for further spread of the species, I decided to eradicate the discovered plants by manual weeding; representative specimens were herbarized and deposited at $K W$.

Nomenclature, morphology, and current distribution of Salsola paulsenii

Salsola paulsenii Litv., Izv. Turkestansk. Otd. Imp. Russk. Geogr. Obshch. [Известия Туркестанского отделения Императорского Русского географического общества] 4(5): 28. 1905. $\equiv$ Kali paulsenii (Litv.) Akhani \& Roalson, Int. J. Pl. Sci. 168(6): 946. 2007.

= Salsola pellucida Litv., Sched. Herb. Fl. Ross. [Список растений Гербария русской флоры] 8
(Fasc. 49): 16, No. 2434. 1913 (Fasc. 49; bound issue with all fascicles published in 1922). = Kali pellucidum (Litv.) Brullo, Giusso \& Hrusa, Phytotaxa 201(4): 271. 2015.

Salsola paulsenii differs from the related widespread species $S$. tragus (rather common in Ukraine) in several quite reliable morphological characters, which are discussed below. A closely related species, S. praecox (Litv.) Iljin (= S. kali var. praecox Litv.; S. paulsenii subsp. praecox (Litv.) Rilke; Kali praecox (Litv.) Sukhor.), which is restricted mainly to Middle/Central Asia, differs from $S$. paulsenii in being usually less robust and smaller, more pubescent, normally having shorter and narrower leaves, smaller anthers, and different phenology (flowering/fruiting in April-August, as compared to June-November for $S$. paulsenii).

Morphological descriptions of $S$. paulsenii and identification keys provided in relevant floristic and taxonomic publications (Iljin, 1936, 1952; Tzvelev, 1996; Rilke 1999; Mosyakin, 2003; Sukhorukov, 2014 etc.) are usually accurate, reliable and diagnostic. Hrusa and Gaskin (2008) provided good illustrations and a comparative table of diagnostic characters of $S$. tragus, $S$. paulsenii, $S$. australis, and $S$. ryanii. Brullo et al. (2015a) also provided a useful comparative table for main morphological characters of $S$. tragus, $S$. paulsenii, $S$. australis and some other related species.

The main characters distinguishing $S$. tragus, $S$. paulsenii, and $S$. pontica, as well as $S$. australis and $S$. ryanii, which may be expected in Ukraine in the future as occasional aliens, are summarized in Table 2. Among these characters, the most obvious ones are the long protruding column formed by the tips of perianth segments above the wings, and bracts gradually tapering into and ending with stiff spines up to $3(-3.5) \mathrm{mm}$ long (Fig. 2). In $S$. tragus the perianth tips are lax and much shorter, and bracts are more abruptly narrowed into a weaker and shorter spine or mucro (Fig. 4). The mature winged perianth in $S$. paulsenii is usually wider than that in $S$. tragus; although sometimes fruits with very diverse wings can be found even on one plant: broadly winged, with wings eroded or dentate at margins, to almost wingless. All these variations were observed in the specimens collected in Kyiv in the Obolon locality. The mentioned wing characters partly depend on developmental stage, position of flowers/ fruits on the branches, and probably some other factors. Moreover, perfectly winged fruits in $S$. paulsenii are usually developed throughout the plant (almost from the base) and at the end of the flowering/fruiting season (Table 2). Lower and middle branches of $S$. paulsenii are 
usually rather long, horizontally spreading to slightly arcuate, with secondary branches forming almost a $90^{\circ}$ angle with the primary branches. Finally, it should be taken into account that $S$. paulsenii is a rather variable species, identification of morphologically intermediate (presumable hybrids), deviant or underdeveloped plants may be problematic, and thus consulting reliably identified herbarium specimens for comparison is advised.

Salsola paulsenii is a tetraploid species with $2 \mathrm{n}=$ 36 (Zakharyeva 1985; Rilke 1999; Lomonosova et al., 2003; Brullo et al., 2015a). Both tetraploid and diploid (sometimes) chromosome counts were reported for S. tragus, but the weedy races most widespread in Eurasia and North America seem to be mainly or exclusively tetraploids (Rilke, 1999; Hrusa, Gaskin, 2008; Brullo et al., 2015a, etc.). The related species $S$. australis is diploid with $2 \mathrm{n}=18$. It is introduced in southwestern North America and southern Africa but most probably is native to Australia, where several other related native species also seem to occur (Kadereit et al., 2005; Borger et al., 2008; Hrusa, Gaskin, 2008; Chinnock, 2010).

The main portion of the native range of $S$. paulsenii covers mostly sandy, sandy-steppe, or sandy-saline habitats of the desert and semidesert zones all around the Caspian Sea (including eastern Azerbaijan and adjacent regions of Russia), Middle and Central Asia (Kazakhstan, Kyrgyzstan, Tajikistan, Turkmenistan, Uzbekistan, eastern and northern Iran, Afghanistan, western Pakistan, western China, southwestern Mongolia) (Iljin, 1936; Grubov, 1966; Pratov, 1972; Rilke, 1999: 159, map in Fig. 75; Freitag, Rilke, 1997; Freitag, 2001; Zhu et al., 2003; Sukhorukov, Akopian, 2013; Sukhorukov, 2014 etc.). In the European part of Russia S. paulsenii was reported as a native species from Astrakhan, Orenburg and Volgograd administrative regions and the Kalmyk Republic (Tzvelev, 1996; Sukhorukov, 2014), and as a rare alien collected in Moscow along railroads (Ignatov et al., 1990; Mayorov et al., 2012). However, Sukhorukov (2014: 335) commented that the species is common in Astrakhan Region but only old herbarium specimens are known from Orenburg and Volgograd regions, and the records from Moscow Region in fact belong to $S$. tragus.

The species is also introduced and naturalized in the southwestern states of the USA (Beatley, 1973; Evans, Young, 1980; Mosyakin, 1996, 2003, and references therein), where it is known under the vernacular name "Barbwire Russian-thistle", because of its rigid and very prickly branches. Rilke (1999: 158) expressed her doubts
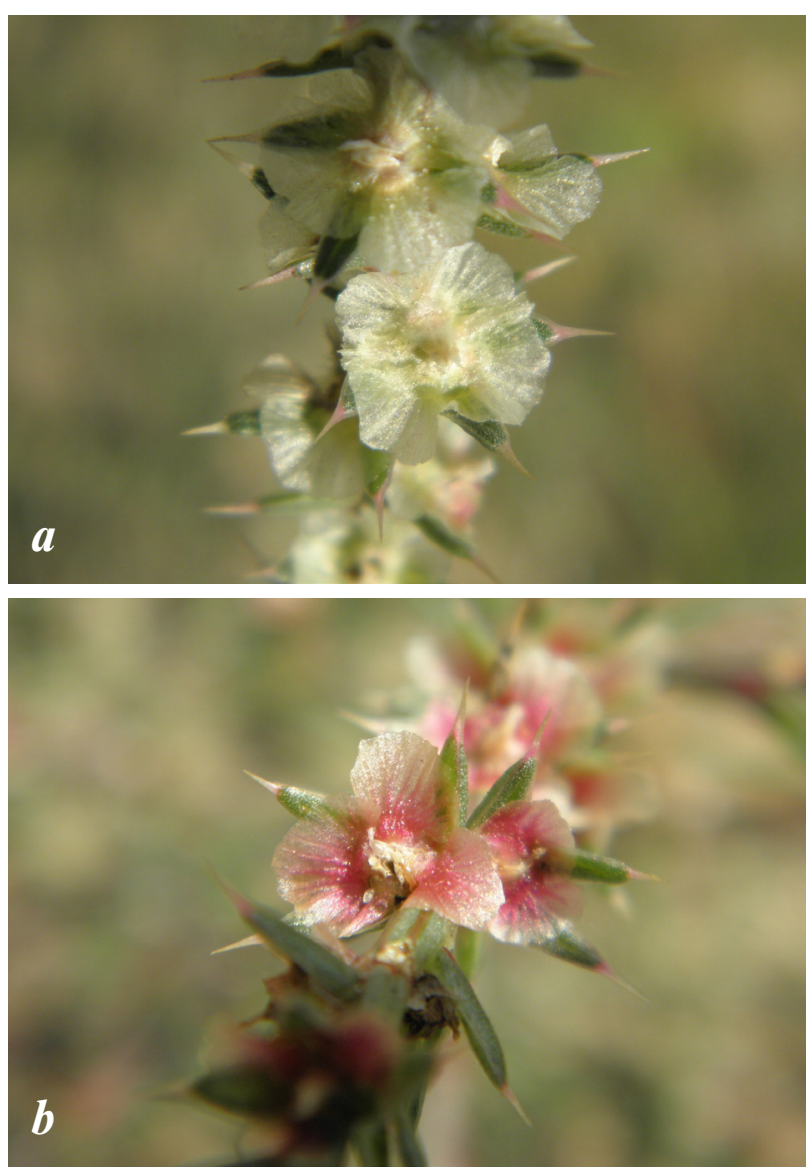

Fig. 4. Salsola tragus: close-up of a branch with fruits and bracts/bracteoles: forms with white $(a)$ and rose-colored $(b)$ wings. Note the short and weak tips of perianth segments, and the bracts and bracteoles more abruptly narrowed into spines

regarding the actual occurrence of $S$. paulsenii in North America and commented that American records of this species need confirmation; however, she also stated that the identification of a specimen from California (Twisselmann 17472 at B) can be confirmed with certainty ["...die amerikanischen Angaben dieser Art eine Überprüfung benötigen! Hier kann ein Beleg aus Kalifornien Twisselmann 17472 (B) zweifelsfrei bestätigt werden."]. Since then, in addition to identifications of North American specimens made or confirmed by Botschantzev and Mosyakin, the rather widespread occurrence of $S$. paulsenii in southwestern North America has been further confirmed by integral studies with application of molecular and micromorphological methods (Gaskin et al., 2006; Hrusa, Gaskin, 2008; Ayres et al., 2009). Moreover, S. paulsenii participates in microevolutionary processes involving some other alien species of Salsola, and occasionally hybridizes with $S$. tragus, forming variable hybrids, some known as 
S. gobicola (Iljin, 1955; Rilke, 1999) and some probably as "Salsola lax" or "S. paulsenii lax", the form with non-spinose or "lax" tips of mature perianth segments (Hrusa, Gaskin, 2008; Ayres et al., 2009 and references therein).

Possible sources of introduction of Salsola paulsenii to Ukraine, and future prospects

In view of the current knowledge of distribution patterns of $S$. paulsenii and considering that its diaspores were evidently brought with grain used for beer brewing at Obolon Co., there are three possible geographical sources for the present introduction of the species to Kyiv: (1) directly from the primary native range in Middle/Central Asia or southeasternmost European Russia; (2) from the secondary range in North America, and (3) from some unidentified areas in southern Ukraine where this species may be spreading unnoticed. We cannot exclude any of those possibilities. However, at present Ukraine is not an importer but exporter of grain (wheat, barley etc.). For example, official data indicate that in 2016-2017 Ukraine exported barley to various countries (the most important being Saudi Arabia, China, Jordan, countries of the European Union, Libya etc.). The total Ukrainian export of grain and grain products at present is also overwhelmingly higher than import: for example, 38 million tons of export against just 171 thousand tons of import (only $0.4 \%$ of export!) for the period of July 2016 - April 2017 [Agravery Agrarian Information Agency: http://agravery.com/uk/ posts/show/import-zerna-v-ukrainu-za-10-misacivsklav-lise-171-tis-tonn (text in Ukrainian)]. Imported grain is represented mainly by rice and corn (maize). These changes in Ukraine's export/import of grain considerably diminished the occurrence of occasional "grain immigrants" (ephemerophytes, non-established alien plants) in the alien flora of Kyiv, as compared to the 1980s and 1990s (Mosyakin, 1991, and unpublished data). Importation of agricultural products from Russia to Ukraine recently shrunk dramatically; the same is true for import of agricultural products from Kazakhstan to Ukraine, where the share of grain is also now nearly negligible [AgGeek: http://aggeek.net/ru/markets/id/ ukraina-i-kazahstan-shans-podelit-shkuru-russkogomedvedja-154/ (text in Russian)].

Direct introduction from North America to Kyiv appears to be less possible because importation of grain and grain products from the US and Canada is now very limited. However, agricultural companies of Ukraine, which operate mainly in the southern and central regions of the country, continue importation of highquality seed (mainly sunflower, corn, soybeans etc.), including seed shipments from the US [AgriNEWS Megaprime Group LLC: http://agrinews.com.ua/ show/305099.html (text in Ukrainian)].

Considering that, it is quite possible that diaspores of $S$. paulsenii were brought to Kyiv with grain from southern Ukraine, which is also most probably true for Grindelia squarrosa, an alien of North American origin that is now naturalized and widespread in the southern and some other regions of Ukraine, and which was cooccurring with $S$. paulsenii in the Obolon locality. If it is the case, there might be yet unnoticed localities of $S$. paulsenii (introduced earlier from the native range or from North America?) in other regions of Ukraine, especially areas of commercial grain production in the south. Judging from its ecological and biogeographic peculiarities and the history of its spread in North America, $S$. paulsenii has a potential to become a noxious environmental (or even agricultural?) weed in Ukraine, especially in the southern regions. The potential spread of that species, however, may be limited by its ecological preferences (mostly open sands and also sandy soils). Despite that, it may occupy in Ukraine the sandy habitats ecologically identical or similar to those already successfully invaded by another prickly alien, Cenchrus longispinus (Hack.) Fernald, which is now locally common and invasive in southern regions of Ukraine, and also in Kyiv (see Mosyakin, 1995; Schanzer et al., 2017). Salsola paulsenii may also hybridize with local weedy races of $S$. tragus, forming potentially invasive stabilized hybrids. Because of that, Ukrainian botanists and agronomists should keep their eyes open for this potentially dangerous new weed.

\section{Acknowledgments}

I am grateful to Prof. Helmut Freitag (University of Kassel, Germany) and an anonymous reviewer for their useful comments on the manuscript. Herbarium assistance of Alisa V. Shumilova and Iryna M. Dyachenko (National Herbarium of Ukraine - KW, M.G. Kholodny Institute of Botany of the National Academy of Sciences of Ukraine) is greatly appreciated.

\section{REFERENCES}

Aellen P. Chenopodiaceae. In: G. Hegi. Illustrierte Flora von Mitteleuropa. Aufl. 2. München: Lehmann Verlag, 19601961 (Reprinted in 1979: Berlin; Hamburg: Paul Parey Verlag.), Bd. 3, Teil 2, pp. 533-747.

Akhani H., Edwards G., Roalson E.H. Diversification of the Old World Salsoleae s.l. (Chenopodiaceae): molecular phylogenetic analysis of nuclear and chloroplast data sets and a revised classification. Int. J. Plant Sci., 2007, 168(6): 931-956, available at: $\mathrm{http}: / / d x . d o i . o r g / 10.1086 / 518263$ 
Akhani H., Greuter W., Roalson E.H. Notes on the typification and nomenclature of Salsola and Kali (Chenopodiaceae). Taxon, 2014, 63(3): 647-650, available at: https:// doi.org/10.12705/633.1

Ayres D., Ryan F.J., Grotkoo E., Bailey J., Gaskin J. Tumbleweed (Salsola section Kali) species and speciation in California. Biol. Invasions, 2009, 1: 1175-1187.

Baranova E.V., Khilova E.V. Materials for geographical characterization of some representatives of anthropophilic elements in the flora of the Southwest of the European part of the RSFSR. Vestnik Leningrad. univ., Ser. 3 (Biol.), 1990, 1(3): 35-44. [Баранова Е.В., Хилова Е.В. Материалы к географической характеристике некоторых представителей антропофильного элемента флоры Северо-Запада европейской части РСФСР. Вестн. Ленингр. ун-та, Сер. 3 (Биол.), 1990, 1(3): 35-44].

Beatley J.C. Russian thistle (Salsola) species in western United States. J. Range Management, 1973, 26(3): 225-226.

Beckie H.J., Francis A. The biology of Canadian weeds. 65. Salsola tragus L. (Updated). Can. J. Plant Sci., 2009, 89: 775-789.

Bentham G. Chenopodiaceae. In: Flora Australiensis: a description of the plants of the Australian territory, London: Reeve and Co., 1870, vol. 5, pp. 150-208.

Blondeau M., Roy C., Bernard J.-P. La soude des collines (Salsola collina Pallas), un adventice nouvelle au Québec. Le Naturasliste Canadien, 2007, 131(1): 24 - 27.

Borger C.P.D., Yan G., Scott J.R., Walsh M., Powles S.B. Salsola tragus or S. australis (Chenopodiaceae) in Australia - Untangling the taxonomic confusion through random amplified microsatellite polymorphism (RAMP) and cytological analysis. Austral. J. Bot., 2008, 56: 600608, available at: http://dx.doi.org/10.1071/BT08043

Botschantzev V.P. The genus Salsola L., a short history of its development and dispersal. Bot. Zhurn., 1969, 54(7): 989-1001. [Бочанцев В.П. Род Salsola L., краткая история его развития и расселения. Бот. жсурн., 54(7): 989-1001].

Botschantzev V.P. A synopsis of Salsola (Chenopodiaceae) from South and South-West Africa. Kew Bull., 1974, 29: 597-614, available at: http://dx.doi. org/10.2307/4108004

Brullo C., Brullo S., Gaskin J.F., del Galdo G.G., Hrusa G.F., Salmeri C. A new species of Kali (Salsoloideae, Chenopodiaceae) from Sicily, supported by molecular analysis. Phytotaxa, 2015a, 201(4): 256-277, available at: http://dx.doi.org/10.11646/phytotaxa.201.4.2

Brullo C., Brullo S., Ilardi V., del Galdo G.G. Kali dodecanesicum (Chenopodiaceae, Salsoloideae) a new species from Greece. Phytotaxa, 2015b, 218(1): 61-68, available at: http://dx.doi.org/10.11646/phytotaxa.218.1.4

Chinnock R.J. Some observations on Salsola L. (Chenopodiaceae) in Australia. J. Adelaide Bot. Gard., 2010, 24: 75-79.

Crompton C.W., Bassett I.J. The biology of Canadian weeds. 65. Salsola pestifer A. Nels. Can. J. Plant Sci., 1985, 65: 379-388.

Ellstrand N.C., Rieseberg L.H. When gene flow really matters: gene flow in applied evolutionary biology. Evol. Appl., 2016, 9: 833-836.
Evans R.A., Young J.A. Establishment of Barbwire Russian Thistle in desert environments. J. Range Management, 1980, 33(3): 169-173.

Freitag H. Salsola. In: Flora of Pakistan. Eds S.L. Ali, M. Qaiser, Karachi: Univ. of Karachi \& St. Louis: Missouri Bot. Garden Press, 2001, vol. 204, pp. 127-178.

Freitag H., Rilke S. Salsola. In: Flora Iranica. Ed. K.H. Rechinger, Graz : Akad. Druck- u. Verlagsanstalt, 1997, vol. 172, pp. 154-255.

Galasso G., Bartolucci F. Notula: 2070 (Kali macrophyllum, comb. nov.) / Notulae alla checklist della flora vascolare italiana: 17 (2027-2070). Informatore Bot. Ital., 46(1): 83.

Gaskin J., Ryan F., Hrusa G.F., Londo J.P. Genotype diversity of Salsola tragus and potential origins of a previously unidentified invasive Salsola from California and Arizona. Madroño, 2006, 53(3): 244-251, available at: http://dx.doi.org/10.3120/0024-9637(2006)53[244:GD OSTA]2.0.CO;2

Grubov V.I. Chenopodiaceae. In: Plantae Asiae Centralis, Leningrad: Nauka, 1966, vol. 2, pp. 3-134. [Грубов В.И. Chenopodiaceae. В кн.: Растения Центральной Азии, Л.: Наука, 1966, т. 2, с. 3-134].

Gubar L.M. New for the flora of Male Polissia species of vascular plants. Ukr. Bot. J., 2004, 61(1): 70-74. [Губарь Л.М. Нові для флори Малого Полісся види судинних рослин. Укр. бот. жкурн., 2004, 61(1): 70-74].

Hernández-Ledesma P., Berendsohn W.G., Borsch T., von Mering S., Akhani H., Arias S., Castañeda-Noa I., Eggli U., Eriksson R., Flores-Olvera H., Fuentes-Bazán S., Kadereit G., Klak C., Korotkova N., Nyffeler R., Ocampo G., Ochoterena H., Oxelman B., Rabeler R.K., Sanchez A., Schlumpberger B.O., Uotila P. A taxonomic backbone for the global synthesis of species diversity in the angiosperm order Caryophyllales. Willdenowia, 2015, 45: 281-383, available at: http://dx.doi.org/10.3372/wi.45.45301

Hrusa G.F., Gaskin J.F. The Salsola tragus complex in California (Chenopodiaceae): characterization and status of Salsola australis and the autochthonous allopolyploid Salsola ryanii sp. nov. Madroño, 2008, 55(2): 113-131, available at: http://dx.doi.org/10.3120/0024-9637(2008) 55[113:TSTCIC]2.0.CO;2

Ignatov M.S., Makarov V.V., Chichev A.V. Conspectus of the flora of alien plants of Moscow Region. In: Floristic studies in Moscow Region. Ed. A.K. Skvortsov, Moscow: Nauka, 1990, pp. 5-105. [Игнатов М.С., Макаров В.В., Чичев А.В. Конспект флоры адвентивных растений Московской области. В кн.: Флористические исследования в Московской области. Ред. А.К. Скворцов, М.: Наука, 1990, с. 5-105.]

Iljin M.M. Chenopodiaceae. In: Flora URSS. Ed. V.L. Komarov, Moscow; Leningrad: Editio Acad. Sci. URSS, 1936, vol. 6, pp. 2-354. [Ильин M.M. Chenopodiaceae. В кн.: Флора СССР. Ред. В.Л. Комаров, М.; Л.: Изд-во АН СCCP, 1936, т. 6, с. 2-354].

Iljin M.M. Species novae Chenopodiacearum ex Asia Centralis. Notulae Systematicae ex Herbario Instituti Botanici nomine V.L. Komarovii Academiae Scientiarum URSS, 1955, vol. 17, pp. 122-143. [Ильин М.M. Новые виды сем. Маревых из Центральной Азии. Ботанические материалы Гербария Ботанического института име- 
ни В.Л. Комарова Академии наук СССР, 1955, т. 17, pp. 122-143].

Iljin M.M. Chenopodiaceae. In: Flora URSR. Ed. M.I. Kotov, Kyiv: Ukr. RSR Acad. Sci. Publ., 1952, vol. 4, pp. 267-313, 650. [Ільїн М.М. Chenopodiaceae. В кн.: Флора Української РСР. Ред. М.І. Котов, Київ: Видво АН УРСР, 1952, т. 4, с. 267-313; 650].

IPNI. The International Plant Names Index (2017-onward). Published on the Internet: http://www.ipni.org (accessed 22 September 2017).

Kadereit G., Borsch T., Weising K., Freitag H. Phylogeny of Amaranthaceae and Chenopodiaceae and the evolution of $\mathrm{C}_{4}-$ photosynthesis. Int. J. Plant Sci., 2003, 164: 959-986.

Kadereit G., Gotzek D., Jakobs S., Freitag H. Origin and age of Australian Chenopodiaeae. Organisms Diversity \& Evolution, 2005, 5: 59-80, available at: http://dx.doi. org/10.1016/j.ode.2004.07.002

Kapralov M.V., Akhani H., Voznesenskaya E.V., Edwards G., Franceschi V., Roalson E.H. Phylogenetic relationships in the Salicornioideae / Suaedoideae / Salsoloideae s.l. (Chenopodiaceae) clade and a clarification of the phylogenetic position of Bienertia and Alexandra using multiple DNA sequence datasets. Syst. Bot., 2006, 31: 571-585, available at: https://doi.org/10.1043/06-01.1

Kühn U. (with additions by Bittrich V., Carolin R., Freitag H., Hedge I.C., Uotila P., Wilson P.G.). Chenopodiaceae. In: The families and genera of vascular plants. Eds K. Kubitzki, J.G. Rohwer, V. Bittrich, Berlin; Heidelberg; New York: Springer, 1993, vol. 2, pp. 253-281.

Kumar V., Spring J.F., Jha P., Lyon D.J., Burke I.C. Glyphosate-resistant Russian-thistle (Salsola tragus) identified in Montana and Washington. Weed Technology, 2017, 31(2): 238-251.

Lojacono Pojero M. Flora Sicula o Descrizione delle piante vascolare spontanee o indigenate in Sicilia, Palermo: Tipo-Litografia Salvatore Bizzarrilli, 1904, vol. 2(2), 428 p. +20 tab.

Lomonosova M.N. Chenopodiaceae. In: Flora Sibiriae. Eds I.M. Krasnoborov, L.I. Malyshev, Novosibirsk: Nauka, 1992, vol. 5, pp. 135-183. [Ломоносова М.Н. Chenopodiaceae / Флора Сибири. Ред. И.М. Красноборов, Л.И. Малышев, Новосибирск: Наука, 1992, т. 5, c. 135-183].

Lomonosova M.N., Krasnikov A.A., Krasnikova S.A. Chromosome numbers of Chenopodiaceae family members of the Kazakhstan flora. Bot. Zhurn., 2003, 88(2): 134-135. [Ломоносова М.Н., Красников А.А., Красникова С.А. Числа хромосом представителей семейства Chenopodiaceae флоры Казахстана. Бот. жмурн., 2003, 88(2): 134-135].

Mayorov S.P., Bochkin V.D., Nasimovich Yu.A., Shcherbakov A.V. The alien flora of Moscow and Moscow Region, Moscow: KMK Sci. Press, 2012, 412 pp. + 120 color tables. [Майоров С.Р., Бочкин В.Д., Насимович Ю.А., Щербаков А.В. Адвентивная флора Москвы и Московской области, М.: Тов-во науч. изд. КМК, 2012, $412+$ 120 (цв.) с.].

Michalková E., Letz D.R. Salsola collina, S. kali subsp. ruthenica, S. soda, S. tragus. Taxon, 2014, 63(6): 1390, E18-E20.
Mosyakin S.L. Floristic finds in Kyiv Polissya (Ukrainian SSR). Ukr. Bot. J., 1988, 45(4): 65-67. [Мосякін С.Л. Флористичні знахідки на Київському Поліссі (УРСР). Укр. бот. жмурн., 1988, 45(4): 65-67].

Mosyakin S.L. Preliminary list of recent additions to the alien flora of the Ukraine. Ukr. Bot. J. 1991, 48(4): 28-34.

Mosyakin S.L. The genus Cenchrus L. (Poaceae) in Ukraine: a review of nomenclature, systematics and current distribution. Ukr. Bot. J., 1995, 52(1): 120-126. [Мосякін С.Л. Рід Cenchrus L. (Poaceae) в Україні: огляд номенклатури, систематики та сучасного поширення. Укр. бот. журн., 1995, 52(1): 120-126].

Mosyakin S.L. A taxonomic synopsis of the genus Salsola L. (Chenopodiaceae) in North America. Ann. Missouri Bot. Gard., 1996, 83: 387-395, available at: http://dx.doi. org/10.2307/2399867

Mosyakin S.L. Salsola. In: Flora of North America north of Mexico. Ed. by Flora of North America Editorial Committee, New York; Oxford: Oxford Univ. Press, 2003, vol. 4, pp. 398-403.

Mosyakin S.L. Notes on taxonomy and nomenclature of Chenopodium acerifolium and $C$. betaceum (C. strictum auct.) (Chenopodiaceae). Phytotaxa, 2017, 324(2): 139-154, available at: https://doi.org/10.11646/phytotaxa.324.2.3

Mosyakin S.L., Fedoronchuk M.M. Vascular plants of Ukraine. A nomenclatural checklist. Kiev, 1999, xxiii + 345 pp., available at: http://dx.doi. org/10.13140/2.1.2985.0409

Mosyakin S.L., Freitag H., Rilke S. Kali versus Salsola: the instructive story of a questionable nomenclatural resurrection. Israel J. Plant Sci., 2017, 64: 18-30, available at: http://dx.doi.org/10.1080/07929978.2016.1256135

Mosyakin S.L., Rilke S., Freitag H. Proposal to conserve the name Salsola (Chenopodiaceae s. str.; Amaranthaceae sensu APG) with a conserved type. Taxon, 2014, 63: 11341135, available at: https://doi.org/10.12705/635.15

Mosyakin S.L., Roalson E.H. New nomenclatural combinations in Pyankovia (Chenopodiaceae). Phytotaxa, 2017, 319(3): 263-270, available at: https://doi.org/10.11646/ phytotaxa.319.3.5

Oldham M.J., Gould J., Bowels J.M. Fetid Dogweed (Dyssodia papposa; Asteraceae) and Slender Russian Thistle (Salsola collina; Amaranthaceae), new to Alberta, Canada. Can. Field-Naturalist, 2011, 125: 366-369.

Ostapko V.M., Boiko G.V., Mosyakin S.L. Vascular plants of the Southeast of Ukraine, Donetsk: Knowledge Publ., 2010, 247 pp. [Остапко В.М., Бойко А.В., Мосякин С.Л. Сосудистые растения юго-востока Украины, Донецк: Ноулидж, 2010, 247 с.].

Pratov U. Chenopodiaceae. In: Identification manual of plants of Central Asia. Critical checklist of the flora. Eds O.N. Bondarenko, M.M. Nabiev, Tashkent: Fan, 1972, vol. 3. pp. 29-137. [Пратов У. Chenородіaceae / Определитель растений Средней Азии. Критический конспект флоpы. Ред. О.Н. Бондаренко, М.М. Набиев, Ташкент: Фан, 1972, т. 3, с. 29-137].

Pyankov V.I., Artyusheva E.G., Edwards G.E., Black C.C., Soltis P.S. Phylogenetic analysis of tribe Salsoleae (Chenopodiaceae) based on ribosomal ITS sequences: implications for the evolution of photosynthesis types. Amer. J. Bot., 2001a, 88: 1189-1198. 
Pyankov V.I., Ziegler H., Kuz'min A., Edwards G. Origin and evolution of $\mathrm{C}_{4}$ photosynthesis in the tribe Salsoleae (Chenopodiaceae) based on anatomical and biochemical types in leaves and cotyledons. Plant Syst. Evol., 2001b, 230: 43-74.

Rilke S. Revision der Sektion Salsola s.l. der Gattung Salsola (Chenopodiaceae). Bibliotheca Botanica, 1999, 149: $1-190$.

Ryan F.J., Ayres D.R. Molecular markers indicate two cryptic, genetically divergent populations of Russian thistle (Salsola tragus) in California. Can. J. Bot., 2000, 78: 5967, available at: https://doi.org/10.1139/b99-160

Ryan F.J., Mosyakin S.L., Pitcairn M.J. Molecular comparisons of Salsola tragus from California and Ukraine. Can. J. Bot., 2007, 85(2): 224-229, available at: https:// doi.org/10.1139/B07-005

Schanzer I.A., Kulakova Y.Y., Kochieva E.Z., Dyachenko E.A. Invasion of Cenchrus longispinus (Hack.) Fernald in East Europe: historical data and assessment of risk. Skvortsovia, 2017, 3(2): 87-88.

Schmalhausen I.F. Flora of Southwestern Russia, or Governorates of Kiev, Chernigov, Volhynia, Podolia, and Poltava, and adjacent territories, Kiev: O.V. Kulzhenko Publ., 1886, xlviii + 783 pp. [Шмальгаузен И.Ф. Флора Юго-Западной России, т.е. губерний: Киевской, Волынской, Подольской, Полтавской, Черниговской и смежных местностей, Киев: Тип. О.В. Кульженко, 1886, xlviii +783 c.]

Skripnik N.P. Chenopodiaceae. In: Manual of vascular plants of Ukraine. Ed. Yu.N. Prokudin, Kiev: Naukova Dumka, 1987, pp. 84-93. [Скрипник Н.П. Chenopodiaceae. В кн.: Определитель высших растений Украины. Ред. Ю.Н. Прокудин, Киев: Наук. думка, 1987, с. 84-93].

Smith L., Hrusa G.F., Gaskin J.F. How many species of Salsola tumbleweeds (Russian thistle) occur in the Western USA? In: Proceedings of the XIII International Symposium on Biological Control of Weeds, Waikoloa, Hawaii, USA, 11-16 September, 2011. Hilo, USA: USDA Forest Service, Pacific Southwest Research Station, Institute of Pacific Islands Forestry, 2013, p. 177.

Sukhorukov A.P. The carpology of the family Chenopodiaceae in relations to problems of phylogeny, systematics and diagnostics of its representatives, Tula: Grif i K., 2014, 400 pp. [Сухоруков А.П. Карпология семейства Сhenopodiaceаe в связи с проблемами филогении, систематики и диагностики его представителей, Тула: Гриф и К., 2014, 400 c.].

Sukhorukov A.P., Akopian J.A. A compendium of the Chenopodiaceae in the Caucasus, Moscow: MAKS Press, 2013, 76 рр. [Сухоруков А.П., Акопян Ж.А. Конспект семейства Chenopodiaceae Кавказа, М.: МАКС Пресс, 2013, 76 c.].

Thiers B. Index Herbariorum. A global directory of public herbaria and associated staff. New York Botanical Garden's Virtual Herbarium. 2017-onward, available at: http://sweetgum.nybg.org/science/ih (accessed 22 September 2017).

Tzvelev N.N. Notes on Chenopodiaceae of Eastern Europe. Ukr. Bot. J., 1993, 50(1): 78-85. [Цвелев Н.Н. Заметки о маревых Восточной Европы. Укр. бот. жсурн., 1993, 50(1): 78-85].
Tzvelev N.N. Tribe Salsoleae. In: Flora Europae Orientalis. Ed. N.N. Tzvelev, St. Petersburg: Mir i Semya-95, 1996, vol. 9, pp. 74-92. [Цвелев Н.Н. Триба Salsoleae. В кн.: Флора Восточной Европы. Ред. Н.Н. Цвелев, СПб: Мир и Семья-95, 1996, т. 9, с. 74-92].

Tzvelev N.N. Salsola. In: Conspectus florae Europae Orientalis. Eds N.N. Tzvelev, D.V. Geltman, St. Petersburg; Moscow: KMK Sci. Press, 2012, vol. 1, pp. 297-299. [Цвелев Н.H. Salsola. В кн.: Конспект флоры Восточной Eвропы. Ред. Н.Н. Цвелев, Д.В. Гельтман, СПб; М.: Тов-во науч. изд. КМК, 2012, т. 1, с. 297-299].

Vidéki R. A Cycloloma atriplicifolia (Spreng.) J.M. Coulter és a Salsola collina Pallas elofordulása Magyarországon. Flora Pannonica, 2005, 3: 121-134.

Voznesenskaya E.V., Koteyeva N.K., Akhani H., Roalson E.H., Edwards G.E. Structural and physiological analyses in Salsoleae (Chenopodiaceae) indicate multiple transitions among $\mathrm{C}_{3}$, intermediate, and $\mathrm{C}_{4}$ photosynthesis. J. Experim. Bot., 2013, 64: 3583-3604, available at: http://dx.doi.org/10.1093/jxb/ert191

Welles S.L., Ellstrand N.C. Rapid range expansion of a newly formed allopolyploid weed in the genus Salsola. Amer. J. Bot., 2016a, 103(4): 663-667.

Welles S.R., Ellstrand N.C. Genetic structure reveals a history of multiple independent origins followed by admixture in the allopolyploid weed Salsola ryanii. Evol. Appl., 2016b, 9: 871-878.

Wen Zh.-B., Zhang M.-L., Zhu G.-L., Sanderson S.C. Phylogeny of Salsoleae s.l. (Chenopodiaceae) based on DNA sequence data from ITS, $p s b \mathrm{~B}-p s b \mathrm{H}$, and $r b c \mathrm{~L}$, with emphasis on taxa of northwestern China. Plant Syst. Evol., 2010, 288: 25-42, available at: http://dx.doi. org/10.1007/s00606-010-0310-5

Wen Z.B., Zhang M.L. Anatomical types of leaves and assimilating shoots and carbon ${ }^{13} \mathrm{C} /{ }^{12} \mathrm{C}$ isotope fractionation in Chinese representatives of Salsoleae s.l. (Chenopodiaceae). Flora - Morphology, Distribution, Functional Ecology of Plants, 2011, 206(8): 720-730, available at: https://doi.org/10.1016/j.flora.2010.11.015

Wilson K.L. Report of the General Committee: 20. Taxon, 2017, 66: 981, available at: https://doi. org/10.12705/664.15

Wilson P.G. Chenopodiaceae. In: Flora of Australia. Ed. A.S. George, Canberra: Austral. Government Publ. Service, 1984, vol. 4, pp. 81-317.

Yena A.V. Spontaneous flora of the Crimean Peninsula, Simferopol: N. Orianda Publ., 2012, 232 pp. [Ена A.В. Природная флора Крымского полуострова, Симферополь: Н. Оріанда, 2012, 232 с.].

Zakharyeva O.I. Chromosome numbers of some flowering plants from the Caucasus and Middle Asia. Bot. Zhurn., 1985, 70(12): 1699-1701. [Захарьева О.И. Числа хромосом некоторых цветковых растений Кавказа и Средней Азии. Бот. журн., 1985, 70(12): 1699-1701].

Zhu G.L., Mosyakin S.L., Clemants S.E. Chenopodiaceae. In: Flora of China. Eds Z.Y. Wu, P.H. Raven, D.Y. Hong; Beijing: Sci. Press \& St. Louis: Missouri Bot. Garden Press, 2003, vol. 5, pp. 351-414.

Recommended for publication by

Submitted 02.10.2017

D.V. Dubyna 
Мосякін С.Л. Перша знахідка Salsola paulsenii (Chenopodiaceae) в Україні та номенклатурно-таксономічні коментарі щодо споріднених таксонів. Укр. бот. журн., 2017, 74(5): 409-420.

Інститут ботаніки ім. М.Г. Холодного НАН України вул. Терещенківська, 2, Київ 01004, Україна

Адвентивний вид Salsola paulsenii (Chenopodiaceae) наведений для території м. Києва: декілька рослин були знайдені у вересні 2017 р. на піщаному грунті на рудеральній ділянці у північно-західній частині Оболоні, вздовж залізничних колій неподалік зернового елеватора та виробничих об'єктів ПрАТ "Оболонь". Наведені відомості про морфологічні особливості та поширення S. paulsenii та деяких споріднених видів. Якщо цей вид закріпиться в Україні, то він може стати інвазійним бур'яном. Розглянуті недавні зміни у систематиці та номенклатурі представників роду Salsola sensu lato. Надана номенклатурна інформація щодо видів флори України, які раніше наводилися у складі Salsola sensu lato, а тепер вміщені до родів Salsola sensu stricto (incl. Kali), Soda, Caroxylon, Climacoptera та Pyankovia.

Ключові слова: Salsola, Chenopodiaceae, Salsoloideae, номенклатура, систематика, флористична знахідка, адвентивний вид
Мосякин С.Л. Первая находка Salsola paulsenii (Chenopodiaceae) в Украине и номенклатурнотаксономические комментарии о родственных таксонах. Укр. бот. журн., 2017, 74(5): 409-420.

Институт ботаники им. Н.Г. Холодного НАН Украины ул. Терещенковская, 2, Киев 01004, Украина

Адвентивный вид Salsola paulsenii (Chenopodiaceae) приведен для территории г. Киева: несколько растений были обнаружены в сентябре 2017 г. на песчаной почве на рудеральном участке в северо-западной части Оболони, вдоль железнодорожных путей поблизости зернового элеватора и производственных объектов ЧАО "Оболонь". Приведены сведения о морфологических особенностях и распространении $S$. paulsenii и некоторых родственных видов. Если этот вид закрепится в Украине, то он может стать инвазивным сорняком. Рассмотрены недавние изменения в систематике и номенклатуре представителей рода Salsola sensu lato. Предоставлена номенклатурная информация о видах флоры Украины, которые ранее приводились в составе Salsola sensu lato, a теперь перемещены в роды Salsola sensu stricto (incl. Kali), Soda, Caroxylon, Climacoptera и Pyankovia.

Ключевые слова: Salsola, Chenopodiaceae, Salsoloideae, номенклатура, систематика, флористическая находка, адвентивный вид 